\author{
LARISA ORLOV VILIMONOVIĆ \\ University of Belgrade, Faculty of Philosophy \\ larisa.orlov@f.bg.ac.rs
}

\title{
THE CULT OF THE THEOTOKOS AND THE FOUNDING OF THE MEDIEVAL NEMANJIĆ STATE: READINGS BETWEEN IMAGE AND PERFORMANCE*
}

\begin{abstract}
This paper aims to analyze the performative aspects of the cult of the Theotokos in the early Nemanjić state. Through an integrative analysis of newly built churches dedicated to Theotokos, with an emphasis on Studenica, ritual texts, and liturgical typikon, I attempt to contextualize the political and ideological background of the newly formed spatial icons of the Theotokos, the reasons and intentions behind them, and function within the historical context surrounding the founding of the Nemanjić State.
\end{abstract}

Keywords: Theotokos, Stefan Nemanja, Sava, Stefan Prvovenčani, performance, Byzantine rite, Theotokos Evergetis, Studenica, spatial icon.

\section{The performative aspects of the cult of Theotokos in Medieval Serbia:} Methodological problems and research trajectories

$\mathrm{T}$ The aim of this paper is to contextualize the political aspect of Marian piety among the members of the Nemanjić dynasty through the theory of performativity. The sources at our disposal include visual and textual material: monastic and church endowments dedicated to the Theotokos, icons of the Theotokos, and literary texts of which the most important are the hagiographies of the ruling members of the Nemanjić dynasty. The theory of performativity enables us to understand the construction of the Theotokos' presence through text, image, and space in the performative act. ${ }^{1}$

I chose the Theotokos as a case study for my research into Nemanjić ideology because of her vital importance for Constantinople. ${ }^{2}$ The 'unique aura of the sanctity of Constantinople

\footnotetext{
* I would like to express my gratitude to my colleague and dear friend Jakov Đorđević whose advice and commentary helped me navigate the theory of performativity and its application to Byzantine art. I am also sincerely thankful to the reviewers whose commentaries and suggestions helped me improve and clarify my overall argument.

1 Sauerbaum, Gragnolati 2010: 3.

2 Earlier scholars noticed the significance of the Theotokos cult for the early Nemanjićes. See for example,
} 
was constructed around various objects of devotion, such as holy images, among which the icons and relics of the Virgin Mary were the most crucial. ${ }^{3}$ Moreover, as a protector of the city's walls and protector of the imperial army in battle, the Theotokos was particularly connected to ceremonies of imperial triumph, during which her icon was carried. ${ }^{4}$

The idiosyncrasy of the textual material at our disposal is its function. The biographies of the Nemanjić rulers and their archbishop were not conceived of as mere secular biographies but as hagiographies of saintly figures who had gained a cult. ${ }^{5}$ As Dimitrije Bogdanović stresses, 'the mere act of writing a Vita was considered a cultic act... an essential part of the founding of the church cult'. ${ }^{6}$ Moreover, the Vitae of Serbian rulers and archbishops had a liturgical function, especially in their introductory parts, which included prayers to God, the Virgin Mary, or other saints. These instances can be seen as performance cues and indicate that these hagiographies were intended to be read aloud before an audience. Through performance, each written text becomes a speech act within a highly ritualized process such as, for instance, the celebration of saints' feast days. On such occasions, I will argue, the liturgical ritual enacted the presence of the Constantinopolitan Theotokos as a mediator in the experience of the sanctity and political legitimacy of the chosen members of the Nemanjić dynasty.

The first two Vitae of St. Simeon, Stefan Nemanja (r. 1166-1196), the founder of the dynasty, were composed by his two sons, Rastko/Sava and Stefan Nemanjić Provenčani (the First-Crowned). Nemanja's death at the Chilandar Monastery on Mount Athos in 1199 marked the beginning of textual production focused on establishing his cult. A key moment in this process was the translation of St. Simeon's holy remains from Chilandar to the Studenica Monastery in 1207, which was the crucial event for the emergence of the cult of St. Simeon.

Sava's literary work played a decisive role in the cult's textual rhetoric. Sava's Vita of St. Simeon was composed around 1208, and it was incorporated into the Studenica Typikon as an introduction. ${ }^{8}$ In the same period, Sava had composed The Divine Service to Saint Simeon, the first text of its kind in Serbian literature. ${ }^{9}$ All three texts- the Typikon, the Vita, and The Divine Service, all from different genres - served similar cultic purposes. They reiterated the image of the saintly founder of the dynasty and paved the way for Nemanja's canonization. Studenica, the monastery of the Theotokos Evergetis, and its central Feast of the Dormition of the Theotokos became the spatial core of the annunciation of Simeon's holiness through myrrh flowing out from his grave.

The performativity of these texts, when read before the audience, enables a reenactment of the narrative in a living moment in which both the performer and the audience

Korać 1968: 51; Babić, Korać, Živković 1986: 16; Kašanin at alli 1986: 9-24; Tatić-Đurić 2007a, Ibid 2007b; Ibid. 2007c; ibid. 2007d; ibid. 2007e; ibid. 2007f; ibid. 2007g; ibid. 2007h passim; for the period $12-15^{\text {th }}$ centuries see Erdeljan 2017.

Ousterhout 2006: 105.

Ousterhout 2006: 105.

Bogdanović 1968: 6.; For more on the development of the cult of St Simeon see Marjanović-Dušanić 1997: $111-117 ; 274$ et sq.

Bogdanović 1968: 9.

Juhas-Georgievska 2005: 7; Juhas-Georgievska 1999; Petrović 1986a: 79-80; Popović 1992: 27.

Juhas-Georgievska 2005: 38; Jovanović 1994: 288; Petrović 1986a: 78-82.

Juhas-Georgievska 1999: 66. 
participate as witnesses to the story. The performative dimension of speech acts refers to a created state of affairs through the use of language that focuses on doing rather than saying. ${ }^{10}$ The rites performed through language utterances 'bring into being the things that they named. ${ }^{11}$ In this paper I will address the invocation of the Theotokos in hymns and praises within the spaces dedicated to her through their performative aspect: what these utterances $d o$, how they create new spaces, and how the textual rhetoric is integrated into visual rhetoric in real social contexts and functions. ${ }^{12}$ Researching the Theotokos enables us to understand the materiality of the sacred and the function of the presence of divine otherness within specific historical and political moments. ${ }^{13}$

Furthermore, these texts' descriptions of ritual events offer a psychological enactment of sacral space(s) available for listeners to 'enter' them. Alexei Lidov proposes the term spatial icons, which are formed during the enactment of a ritual. ${ }^{14}$ This paper will explain these spatial icons through the oral performance of sanctified written narratives containing verbal visualizations of saints, relics, and holy images.

Stefan Nemanja's two most prominent monastic endowments are the monasteries of Studenica and Chilandar on Mount Athos. Both were dedicated to the Theotokos. The visual representations inside the churches, their dedication to and the central feasts celebrating the Theotokos, and the holy icons of the Theotokos in dialectic with the people's performances within these spaces all made Studenica and Chilandar the central loci of Marian devotion in medieval Serbia. Both monasteries functioned as the 'perceived, conceived, and lived spaces' of the Theotokos's holy presence in medieval Serbia. ${ }^{15}$ However, my analysis will only focus on Studenica because of Chilandar's formal and ideological peculiarities. Chilandar was reserved only for monastic communities, and did not permit the laity to participate in rituals within its space. The ideological importance of Chilandar is unquestionable, but my attention here will be focused on the spaces constructed for performative communication among various groups of medieval Serbian society.

My main interest lies in Studenica's 'intrinsic symbolic value' ${ }^{16}$ as a sacral space par excellence for the Theotokos' actual dwelling place. The more difficult but most important question concerning the interplay of space and the performative function of language is 'the question of what is the act that a literary performative accomplishes' ${ }^{17}$ We also need to consider Butler's observation that 'performative acts are forms of authoritative speech', which 'perform a certain action and exercise binding power'. ${ }^{18}$ According to Butler, the power of authority lies in the repeated citation of norms and the application of rules connected to the legacy of tradition, longevity, and iterability. The utterance of similar words and phrases recreates social bonds within various communities through time and across

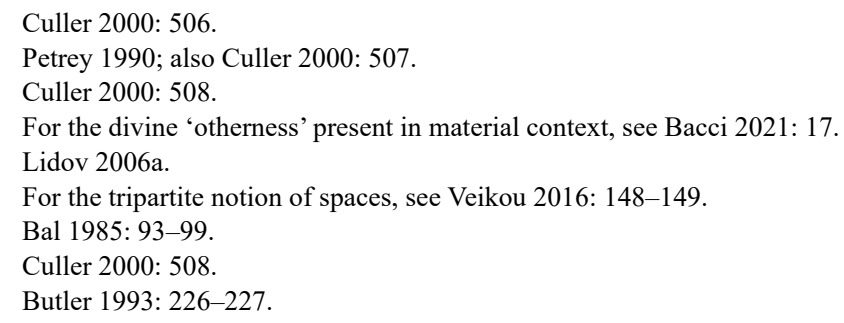


spaces and places. This notion will be crucial for understanding the immense importance of the transfer of the Byzantine liturgy for constructing authority in medieval Serbia and its connection to Byzantine power structures.

Hence, I will use narrative sources within the emergence of the Theotokos's sacred spaces in medieval Serbia and interpret the political and ideological importance of the Theotokos for the founding of the Nemanjić state. The idea behind this analysis is to particularize and localize the 'pan-Christian' cult of the Theotokos and assess its political and ideological importance within medieval Serbia.

\section{Stefan Nemanja and the Theotokos:}

\section{Safe passage between earthly death and saintly life}

The central loci of the cult of the Theotokos in medieval Serbia were established during the time of Grand župan Nemanja (r. 1166-1196). With the backing of Emperor Manuel I Komnenos (1143-1180), and Archbishop of Ohrid John (Adrian) Komnenos (in office from 1140-1164), Nemanja established his first monastic endowment, the Church of the Most Holy Theotokos, in Toplica near Kuršumlija, in southeast Serbia. ${ }^{19}$ Nemanja restored a church that had already existed on that spot, and art historian Ivan Stevović, in particular, emphasizes the significance of the restorations. ${ }^{20}$ A biographer of Stefan Nemanja, his middle son, Stefan the First-Crowned, places the family conflict between Nemanja and his brothers as occurring after Nemanja built his first two endowments, the Church of the Theotokos and the Church of St. Nicholas in Toplica, which had been built 'in the vicinity of the Theotokos'. ${ }^{21}$ The fraternal conflict was resolved on the battlefield near the village of Pantina in 1166, from which Nemanja emerged as the victor, thus becoming grand župan of all the Serbian lands. Although this source provides little information, Stevović proposes a new historical and ideological context for the Theotokos in Toplica based on its architectural style, which brings us to the two most prominent Marian shrines in Constantinople, Blacherne and Chalkoprateia. ${ }^{22}$ Nemanja's restoration of the old Church of the Theotokos can be viewed within the broader context of the restoration of Manuel's imperial power in the Balkans. ${ }^{23}$

A potential of translation of the 'spatial core' of the Theotokos churches in Constantinople by way of architectural style is emblematic of the essence of our understanding of performance. Enacting a ritual venerating the Theotokos within the same spatial core had profound political, ideological, and theological implications for both the center (Constantinople) and the periphery (Serbia). The Church of the Theotokos in Toplica is significant for the political hierotopy of the Theotokos cult as a construction of sacred spaces related to the political dynamic between Serbia and Constantinople.

Stefan Nemanja's construction projects were a reflection of his far-fetching political

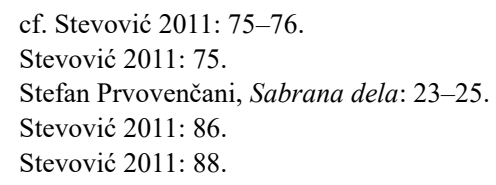


ambitions. Once he had built the church dedicated to St. George, a patron saint who had saved him from the cave where his brothers had imprisoned him, Nemanja entered the most important phase of his political life - the consolidation of his sole rule. ${ }^{24}$ Nemanja's power was further augmented when he built the most prominent endowments from the Nemanjić period dedicated to the Mother of God - the Studenica Monastery (1186) in the Bishopric of Ras, in central Serbia, and its main church dedicated to the Virgin Evergetis and the Dormition of the Virgin Mary; and the Athonite Monastery of Chilandar (1198) and its main church dedicated to the Presentation of the Blessed Virgin Mary. ${ }^{25}$

The sacral topography of Nemanja's earthly death and the beginning of his saintly afterlife was linked to the powerful presence of the Theotokos. The scene of Nemanja's death described in the two Vitae is marked by the presence of 'the Theotokos, to whom he had given a vow that he would deliver his soul to her. When he felt that his final hour was upon him, he had asked for the Icon of the Theotokos to be brought to him '. ${ }^{26}$ It is believed that the icon brought to Nemanja was a sizable mosaic icon $(56,5 \times 38 \mathrm{~cm})$ similar to the Virgin Hodegetria ('She who points the way') in Constantinople, which was most likely the patron icon of Chilandar. ${ }^{27}$

The ideological importance of the Theotokos Hodegetria was its function as the living protector of Constantinople. Her presence was invoked through her miraculous appearance in the 'actual urban space of Constantinople' during a regular Tuesday procession, and was one of the primary examples of Byzantine hierotopy ${ }^{28}$ Her distinctive connection to the Komnenian dynastic cult and its funerary practices was made during these Tuesday processions, which had included the new imperial mausoleum, the Monastery of the Christ Pantokrator. ${ }^{29}$ The Typikon of the monastery stipulated the following: 'The holy icon of the emperor's 'most pure Lady and Mother of God Hodegetria' should be taken into the monastery on the days commemorating the ktetors, and be placed in the Church of Saint Michael near their tombs' ${ }^{30}$ Thus, the miraculous performance of the Hodegetria, which created 'a mystical link between' the people of Constantinople and 'their main intercessor,' created yet another mystical link: one between the members of the Komnenian dynasty and their heavenly protector, which was deeply intertwined with their funerary practices. ${ }^{31}$

The Theotokos was also personally significant for other highly prominent members of the Komnenian oikos such as Isak Komnenos (1093-1152), the younger brother of Emperor John II Komnenos, who fell into disfavor during his brother's reign. His final resting place, the Monastery of the Theotokos Kosmosoteira housed his tomb with the icon of the Theotokos as Kosmosoteira, framed in gold and silver, and another of Christ. [Also

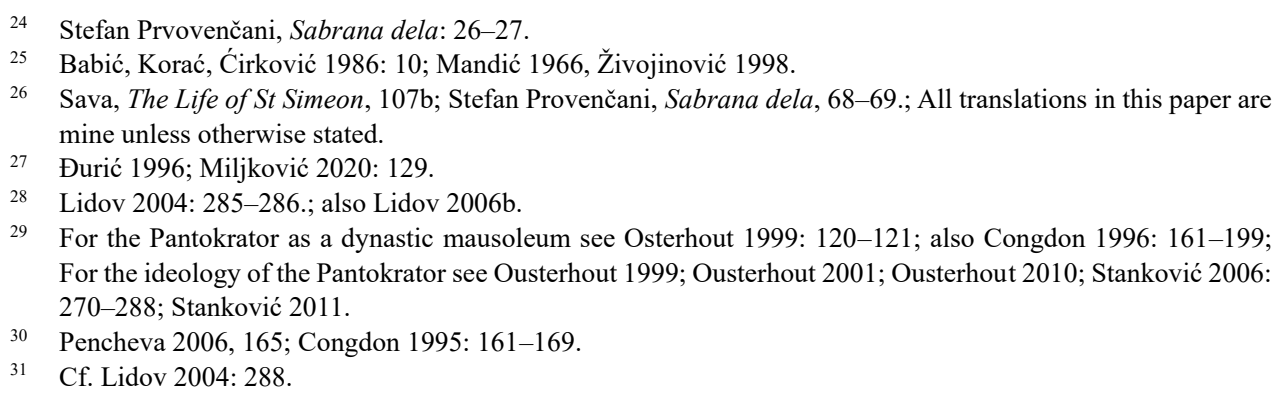

29 For the Pantokrator as a dynastic mausoleum see Osterhout 1999: 120-121; also Congdon 1996: 161-199; For the ideology of the Pantokrator see Ousterhout 1999; Ousterhout 2001; Ousterhout 2010; Stanković 2006: 270-288; Stanković 2011.

30 Pencheva 2006, 165; Congdon 1995: 161-169.

31 Cf. Lidov 2004: 288. 
an] encolpion of the Theotokos was to be set in silver on the lid of the tomb'. ${ }^{32}$ Theotokos Kosmosoteira was the intercessor for his soul in his final hour, and she was his personal protector: 'I, the restorer of the holy monastery, as has been said, have set forth in burning faith for my benefactress, the Mother of God and Kosmosoteira. An unblemished ally in every sense, I now invoke thee, since it is with thine aid, o all-seeing universal queen, that I would express the wishes nourished in this now so wretched mind of mine'. ${ }^{33}$

The immense ideological importance of the Hodegetria and the Theotokos Evergetis in the Komnenian context was recreated in the funerary rituals of the emerging cult of St. Simeon. The scene of Nemanja's death in the Vita appears as a narrative reconfiguration of the Kanon eis Psychorragounta (Kanon for He Who Is at the Point of Death). Although there is no direct mention of the canon in the Vita, the text is paradigmatic of the Byzantine notions of the afterlife and the process of the soul separating the from the body. ${ }^{34}$ In this canon, the Theotokos plays a key role as the one 'who will protect the soul from demons' and who will entreat Christ for mercy through her maternal right. ${ }^{35}$ As is evident from the Typikon of Kosmosoteira, the Thetokos had a pivotal intercessory role in the salvation of Isaac Komnenos' soul. ${ }^{36}$ The icon of the Theotkos Simeon asked for echoes the visual representation of this kanon from the Chorologion of the Akoimeton monastery (Leimonos MS 295). The theme of the soul separating from the body is depicted as a scene of a dying monk whose upper body is covering the icon of the Theotokos. ${ }^{37}$ The last hymn of the kanon stresses that the Theotokos' prayers are like those that could call a condemned soul back from Hades. ${ }^{38}$

In this case, the Theotokos Hodegetria was connected to the funerary rituals of Stefan Nemanja and his wife Anna/Anastasija. ${ }^{39}$ Nemanja's dying scene at Chilandar before the icon of Hodegetria could be connected to Anna/Anastasia's final resting place in Studenica protected by Hodegetria, thus uniting the Theotokos spaces in Studenica and Chilandar under the palladium of the empire, Hodegetria (Figure 1). ${ }^{40}$ The Chilandar Monastery, according to Sava's Vita of St. Simeon, 'had grown from being insignificant and small to being a magnificent site through the help of the Theotokos Hodegetria (Bogorodice $i$ Nastavnice naše) and the lord Simeon (Figure 2). ${ }^{41}$ The Chilandar Monastary was dedicated to the Theotokos Hodegetria. ${ }^{42}$

Chilandar's founding charter (1198) describes Nemanja's earthly reign as 'Christ anointed,' but his taking monastic vows and withdrawing from Serbia, and his final hours, death, the translation of his remains, and his saintly afterlife are all associated with the Theotokos. All the events connected to the Theotokos constitute the rhetorical and

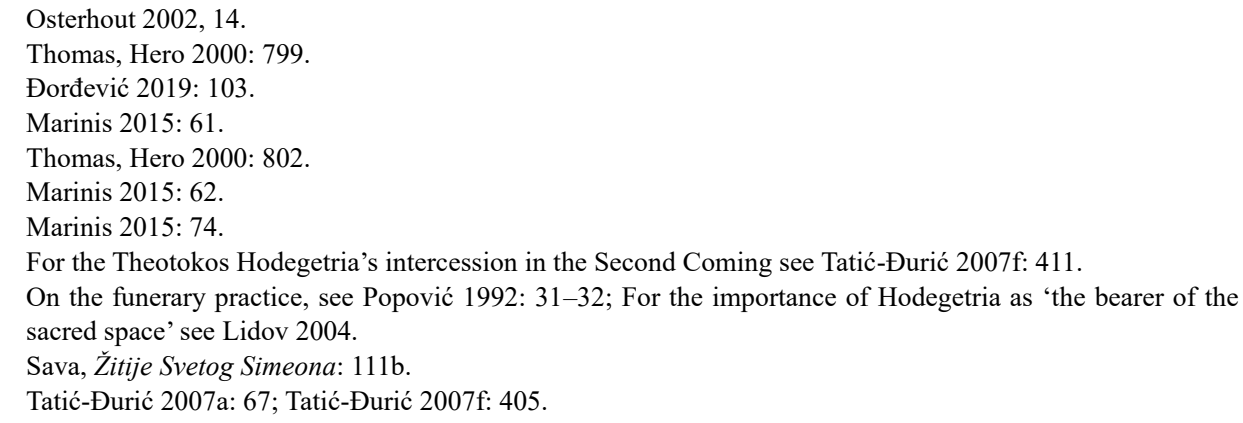


ideological precondition for the cult of the blessed Simeon. Stefan Nemanja took monastic vows in Studenica, while his wife, Anna, became the nun Anastasija and withdrew to Nemanja's first endowment, the monastery in Ras dedicated to Theotokos.

The Virgin Hodegetria in Stefan Nemanja's possession placed both Chilandar and his polity on the map of Byzantine power-cartography. It set the scene for the construction of the image of of Nemanja as a chosen one. Nemanja delivered his soul to the Theotokos on Mount Athos, the 'Holy land of the Theotokos.' The translation of his remains from Chilandar to Studenica 'into the tomb which he had already prepared for himself' was conducted in $1207 .{ }^{43}$ The revelation of his holiness started with the miracles at his tomb. ${ }^{44}$ By becoming a place of both burial and miracle where the holiness of the founder of the Nemanjic dynasty was revealed, Studenica very soon was transformed from a sacred space into a holy site, which, according to Bacci, is 'a site-bound manifestation of both individual and public worship by taking the form of martyr's tomb and memorial sites working as a visual witness to some major events of both the Gospels or the saint's heroic lives'. ${ }^{45}$ Through the rites performed within this space that commemorate the day of Simeon's death and the Feast of the Dormition of the Theotokos, Studenica became a holy site that enabled more direct access to the experience of Nemanja's chosenness and a particular connection to the Constantinopolitan Theotokos. The association of the funeral rite at Studenica with the performance of the liturgy closely resembled the design of the imperial mausoleum of Christ Pantokrator. ${ }^{46}$

The importance of the Theotokos in the political discourse of the early Nemanjić dynasty is also confirmed in a fresco in the exonarthex of Studenica (c. 1233/34) depicting the translation of St. Simeon's holy remains from Chilandar to Studenica. Ahead of the procession, is an icon of the Theotokos Paraklisa. ${ }^{47}$ Bojan Miljković concludes from this composition that Studenica was a focal place of the Theotokos cult in the Nemanjić state, and it housed at least two highly venerated icons of the Theotokos. ${ }^{48}$ As a repository of sacred icons, Studenica enabled an ongoing invocation of the relationship between Stefan Nemanja and the Theotokos in locative and ritual functions. ${ }^{49}$

\section{Approaching the polysemy of Studenica (Figure 3)}

Scholars unanimously agree that the Studenica Monastery 'holds an unparalleled place in the sacral topography of the Serbian lands and constitutes a cornerstone of Serbian history'. ${ }^{50}$ The first phase in the construction of the monastic complex began in the $1180 \mathrm{~s}$ and had been completed by 1196 when Stefan Nemanja joined the monastic community. ${ }^{51}$

According to the art historian Jelena Erdeljan, Studenica functioned as 'a sign and a

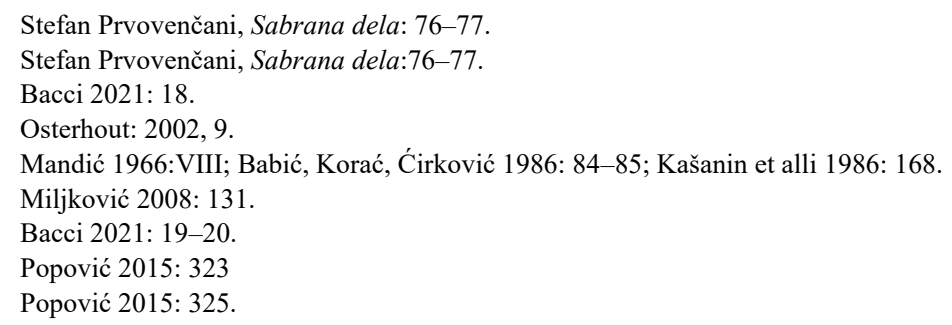


paradigm' of the construction of 'New Jerusalems' in the Slavia Orthodoxa. This was achieved, she says, though its visual and spatial rhetoric and its function as 'a locus sanctus of the Nemanjić dynastic cult' ${ }^{52}$ However, Robert Ousterhout argues that the construction of Constantinople as a New Jerusalem should be reconsidered, and although it could be linked to Jerusalem in 'heavenly and earthly aspects,' it was neither a replica nor a replacement of the prototype. ${ }^{53}$ In the light of his observations, Studenica's identity could arguably be explored as one of a New Constantinople rather than a New Jerusalem, which also has clear ideological implications. The importance of the Constantinopolitan provenance of Studenica's ideology is based on the sanctity that was 'introduced and perpetuated within a complex system that interwove power and status' ${ }^{54}$

Studenica's multifaceted and multi-layered rhetoric was an outcome of a long process in which each member of the early Nemanjic family played a part. The meaning and importance of Studenica for Stefan Nemanja and his sons, Sava, Stefan Nemanjić, and even Vukan, varied and changed throughout the years of its prolonged construction.

The construction of Studenica occurred within the political context of the ambitious politics of the archbishop of Ohrid, who sought a loyal ally in the Balkan hinterland. The imperial anti-heretical policy was, according to Jelena Erdeljan, the reason for Nemanja purging his lands of the Bogomils, and the final triumph of his Orthodoxy was embedded in the ideology of Studenica. ${ }^{55}$

Another essential part of Studenica was its function. Although it is assumed that Studenica might not have initially been built as a burial place for Stefan Nemanja and his wife Ana, it in fact became a family mausoleum during Nemanja's lifetime. ${ }^{56}$ As Robert Ousterhout remarks about twelfth century Byzantine funerary architecture, 'At the Church of the Virgin of Studenica, constructed after 1183, the atrophied cross plan of the naos, common to Byzantine architecture, is expanded by an extra bay between it and the narthex. It was here that the royal founder, Stefan Nemanja, chose to be buried. Like the Kosmosoteira, the Church at Studenica 'was given an extension on account of the tomb'. ${ }^{57}$

Studenica had a pivotal role in early Nemanjić ideology as a reliquary and depository of the holiest relic - a fragment of the True Cross. ${ }^{58}$ As such, it closely resembled the Holy Chapel at the Church of the Theotokos of the Pharos in Constantinople. ${ }^{59}$ Even though the choice of Studenica as Stefan Nemanja's final resting place may not have been what it was first intended for, Nemanja's choice to be buried at Studenica was emphasized in the Vita composed by his successor, Stefan the First-Crowned. ${ }^{60}$

Stefan states the following: 'We have welcomed the holy relics of Saint [Simeon] and

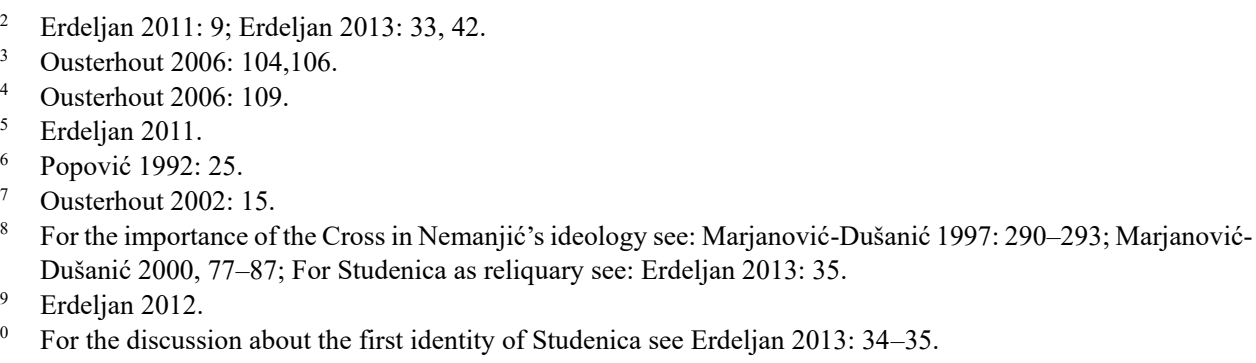


escorted them to a tomb already prepared at the Most Holy Theotokos of Studenica, which he himself had prepared'. ${ }^{61}$ The whole chapter stresses Stefan's request to Sava to transfer Nemanja's holy remains from Chilandar to Studenica as a token of familial reconciliation.

Studenica, the chosen place for the dynastic cult, became the spot where Stefan the First-Crowned was administered monastic vows by his younger brother, Archbishop Sava, before his death on September 24, 1223. Stefan's remains were buried at Studenica 'next to his holy father Simeon in the house of the Most Holy Theotokos of Studenica' ${ }^{62}$

\section{Sava and Theotokos: Behind the liturgical hierotopy}

Studenica had a multi-layered connection to the Monastery of Theotokos Evergetis (Theotokos the Benefactress) in Constantinople. ${ }^{63}$ The Studenica Typikon was based on the highly influential typikon of the Theotokos Evergetis from the late eleventh and early twelfth centuries ${ }^{64}$ Two of the imperial typika of the Komnenian period, the Kecharitomene and the Kosmosoteira, were based on the text of the Evergetis. ${ }^{65}$

Both Stefan Nemanja and his son Sava had a particular connection to the Monastery of Theotokos Evergetis, of which they were considered the second ktetors. ${ }^{66}$ In the written sources, Studenica's primary fresco and icon, the Bogorodica Studenicka, is often called the Bogorodica Evergetis, and Studenica is denoted as the House of the Holy Theotokos Evergetis. ${ }^{67}$ The Typikon of the Evergetis strongly emphasized the liturgy, stipulating it as the community's primary duty even before manual labor. ${ }^{68}$ Thus, another translatio was enabled - the transfer of the Byzantine rite, which enabled a liturgical hierotopy to be enacted and performed. ${ }^{69}$ The central feast in the liturgical calendar was the Dormition of the Theotokos. ${ }^{70}$ The feast was to be celebrated as the Feast of Feasts according to the dictates of the Evergetis Typikon. It was also the central feast contained in two imperial typika influenced by Evergetis - those of the of the monasteries of Kecharitomene and Kosmosoteira. ${ }^{71}$

The synaxarion (liturgical typikon) of the Evergetis was based on several earlier typika: the Stoudion, the liturgical typikon of the cathedral church of Hagia Sophia; and the lost typika from Mount Olympos, which contained a tract from the patriarch Anthony III Studite concerning the Office of the Annunciation. ${ }^{72}$ The ideological legacy the Evergits typikon drew from took a militantly anti-heretical position and had a strong aversion to unlimited imperial authority that was based on the premise of 'institutional independence

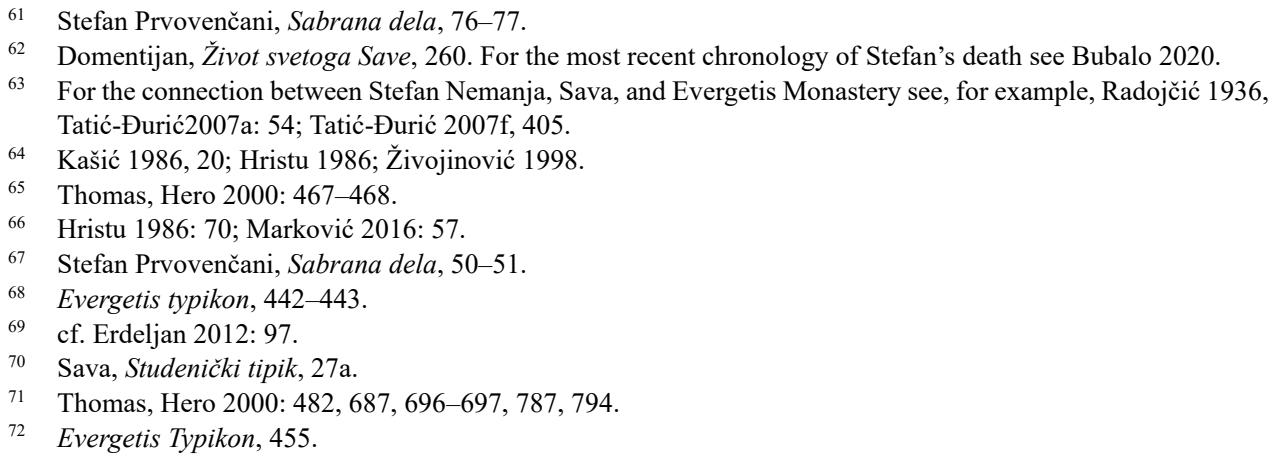


and self-government'. ${ }^{73}$ The chapter on the monastery's self-governing rules contains the following (emphasis added):

\footnotetext{
We instruct all in the name of our Lord God, the Ruler of All, that this holy monastery is to be independent, free of anyone's control, self-governing, and not subject to any rights, be they imperial or ecclesiastical, or of an individual, but it should be watched over, guided, governed, and directed only by the Mother of God Evergetis who is worthy of all praise, by the prayer of our most blessed and holy father, and by the one acting as superior in it, and furthermore in accordance with the chrysobulls of the emperors now dead, by which its independence and freedom from all control is most strongly asserted for you, and through which you will have independence undisturbed, fully steadfast and unshaken. ${ }^{74}$
}

The same rule (n.12) appears for Studenica, in which the monastery is to 'be independent among all the governing ones, free of any supervision, not subject to any other rights, but governed only by the Mother of God and Benefactress [Evergetis] and by the prayer of our venerable father, and consolidator, [by] the one acting as abbot in it'. ${ }^{75}$ As Panaiotis Christu emphasizes, the political agenda behind the Studenica Typikon was to limit the influence of the Ohrid archbishopric. Thus, Studenica was conceived as a forerunner to the Serbian autocephalous Church. ${ }^{76}$

Also, using the synaxarion of the Great Church as a foundation enabled the translation of the liturgical performance of the Great Church, which was unique in all of Christendom. As Robert Taft points out, 'in no liturgical tradition' has 'one edifice played such a decisive role as Hagia Sophia,' thus making both the outer and inner spaces of the temple an integral part of the liturgy. ${ }^{77}$ The very space of the Great Church, rather than 'its decoration,' created an impression of a 'heaven on earth, the heavenly sanctuary, a second firmament, image of the cosmos, throne of the very glory of God' ${ }^{78}$ Thus, subtly and indirectly, the spatial icon being formed during the rites conducted in Studenica invoked the idea of a holy space in which the mediators of the Theotokos were the members of Nemanjic family.

The Theotokos Evergetis of Studenica served as a legitimizing ideological force for the founders of the northern polity. Under the protection of the Theotokos Evergetis, Stefan Nemanja entered the last phase of his political life and the consolidation of his rule. The belief that Studenica was the Theotokos's prime locus sanctus in Serbia is evident in the Studenica Typikon. Through Studenica Typikon, Sava built a liturgical manifesto for an independent Serbian Church, while subtly using the Evergetis Typikon to suit his political needs. The most significant element in this process is the rite performed at the investiture of the archimandrite of Studenica, which was a unique position first granted specifically to Sava.

The monastery was envisioned as a 'ruler's monastery' that should only be in the hands of 'those who rule the country'. ${ }^{79}$ The election of its abbot (archimandrite) was to be conducted by a council of bishops and abbots from 'St. George in Ras, of Holy Mother of

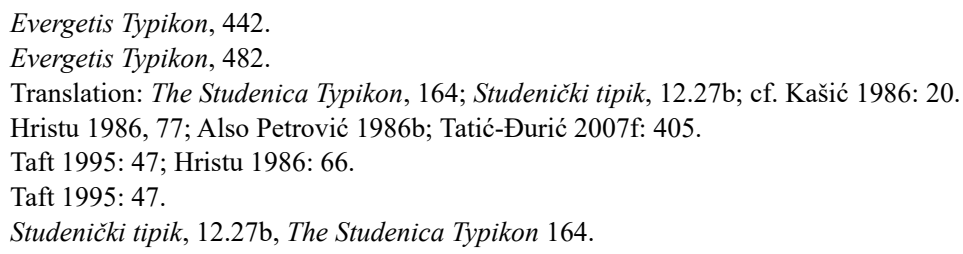


God in Gradačka, St. Nicholas in Toplica, the other Nikolas in Kazanovići, and the other St. Nicholas in Dabar, and St. Geroge in Dabar' that was led by the 'ruler of all Serbian land' ${ }^{80}$ The installation of the archimandrite was followed by a liturgy in which the Holy Gospel was placed on the holy table and the cane 'before All Holy [Theotkos]'. After the end of the liturgy, and the troparia Kyrie eleison, troparia and kondakion to the Dormition of the Most Holy [Theotokos], all abbots 'give the Holy Gospel to the installed, and take him before the doors. The state Master of the entire Serbian land approaches and takes the cane from the hands of the Holy Mother herself, and gives it to the abbot. Guiding him, he instills him at the Abbot's place, and says to him: 'The worthy'. And all respond at out loud at the same time: 'Worthy!' And they bestow him with a kiss, the ruler first, then the patron [bishop], then the rest of the honorable elderly in an orderly manner... Then the ruler is celebrated, and the Archimandrite installed'. ${ }^{81}$

The archimandrite was expected to be the ruler's ecclesiastical 'deputy,' the keeper of 'this holy temple' and this 'holy place.' In return, the ruler will be 'protected by the Most Holy Despoina and Lady Theotokos Evergetis, both in this world and in the next.' The typikon once again stresses that this place is to be excluded from the 'jurisdiction of the bishop'. ${ }^{82}$

The presence of the Theotokos was invoked through these rituals. The focal point during the investitures of the monastery's leading officials was the icon of the Most Holy Theotokos along with the phrase 'as if she' gives or appoints. The phrase focuses on what is being done rather than what is said, thus invoking the materiality of the sacred through the performative aspect of this speech act. The presence of the Divine - the Theotokoswithin the sacred space of Studenica at that specific historical and political moment gave the Serbian ruler and archimandrite the force of authority sanctioned by Byzantium.

The ritual of the investiture of the archimandrite vividly summarizes how the performance of the liturgy and the order of officials had staged a new hierarchy that was in defiance of a real political hierarchy. In the Thetokos's newly constructed space, the leading figure was the ruler of all the Serbian lands who, similarly to the Byzantine rite reconfigured from the Evergetis Typikon, leads the investiture of (monastic) officials and whose heavenly protector is the Theotokos. He presents to the archimandrite an insignia of worldly power, and he stands before the bishop of Ras, who has no jurisdiction over this place.

Judging from this important passage, it seems reasonable to assume that this typikon was based around Sava's investiture as the archimandrite of Studenica in the first decade of the twelfth century (most probably around 1208). ${ }^{83}$ Although very similar to the Typikon of Chilandar, it was arguably an independent adaptation of the Evergetis Typikon. ${ }^{84}$ The most important divergence between Chilandar's typicon and that of Studenica was the chapter on the monastery's autonomy. ${ }^{85}$ The installation of Sava as the first Serbian archimandrite was,

Studenički tipik, 13.30a; The Studenica Typikon 166.

Studenički tipik, 13.31b.

Studenički tipik, 13.32a; Meaning that others exercise no power over any territory or over the monastery, except for the Archimandrite.,The Studenica Typikon, 168, n.84.

83 The first abbot of the monastery, Dionisius, is mentioned during the translation of St Simeon's remains, which means that the archimandrite's investiture occurred in 1207-1208, Komatina 2016: 260.

84 Hristu 1986: 70.

85 Komatina 2016: 260. 
according to the sources, the choice of his brother Stefan (who would later become the FirstCrowned) ${ }^{86}$ It was Stefan Nemanjić and Sava who were the very first protagonists of this solemn ritual.

As is evident from the list of abbots, all of the most prominent monasteries were dedicated to St. Nicholas and St. George, who were considered patron saints of Stefan Nemanja during the early phase of his political career. As for the Theotokos, her place was reserved for the holiest temple, which from its inception carried a 'royal' status. One of Studenica's walls was inscribed with Stefan Nemanja's entire chrysobull, which arguably was the first mention of his title as 'autocrat of the Serbian lands and the littoral' ${ }^{87}$ Thus in its inner and outer spaces and with its liturgical performance, dedication to the Theotokos, connection to Constantinople, and with the meaning and function it had for the founders of the Nemanjić state, Studenica served as a cultic narrative and a living icon of a new sacred space and a new Holy Kingdom.

Studenica had a pivotal role in the power dynamic between Byzantium and Serbia, and through its visual, spatial, and textual rhetoric, it declared a significant amount of political independence, which would eventually lead to the formation of the Serbian Autocephalous Church (1217) and Serbia's elevation to a kingdom (1219).

The idea of independence was delicately deployed in the typikon's renowned twelfth chapter: 'This holy monastery, together with the Abbot, I entrust to the one who rules this land, to the Great King who shall be in the times to come' ${ }^{88}$ This subtle borrowing from Matt. 25:1 was Sava's amendment to the Evergetis's rule. The Evergetis's self-governance under the abbot, repeatedly stressed and emphasized through references to imperial charters, was adapted for Studenica's own self-governance under the ruler of Serbia, 'the Great King who shall be in the times to come,' namely Stefan the First-Crowned. ${ }^{89}$

\section{Stefan the First-Crowned and the Theotokos: She 'who chose him to be the heir to his father's house'}

Researchers usually attribute the initiative to construct the dynastic cult at Studenica to Sava, which is not an incorrect conclusion but is rather an incomplete one. The dynastic cult was important specifically for Stefan the First-Crowned, the only one who could continue the dynasty through his progeny. I argue that Sava, along with Stefan the FirstCrowned, constructed the concept of a dynasty sanctioned by the Theotokos. Stefan's rise to power within the family was infused with the symbolic capital of the Theotokos of Constantinople. As I have shown, the crucial site for the invocation of the Theotokos's presence was Studenica, a focal sacral locus in early Nemanjić Serbia. Studenica had a dual role: to propel the sanctification of the members of the Nemanjic dynasty and to reflect the power dynamic within the Byzantine sphere of influence. ${ }^{90}$ The right to build a new

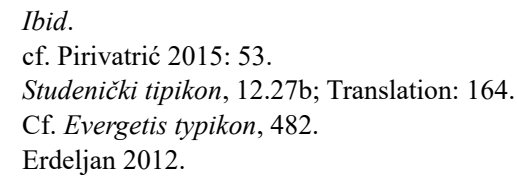


monastery on Mount Athos dedicated to the Theotokos was granted to Stefan Nemanja in 1198 by Alexios III Angelos (1195-1203), father-in-law to Stefan the First-Crowned. In Nemanja's founding charter for the Chilandar Monastery, he states that he built the monastery with the help of his son the grand župan and sebastokrator Stefan, whom he had 'blessed just as Jacob had blessed his son'. ${ }^{91}$ Stefan the First-Crowned became the second ktetor of Chilandar after his father, for which he issued a charter (1207/1208). ${ }^{92}$

The choice of Stefan the First-Crowned as heir to the Principality of Serbia instead of his elder brother, Vukan, directly resulted from his change of status within the Byzantine court hierarchy. Stefan was married to Eudokia, daughter of Alexios III Angelos (11921202). When Alexios ascended the throne in 1195, Stefan became a sebastokrator, a member of the emperor's inner family circle. The change of emperor directly influenced Nemanja's choice to take monastic vows and abdicate his secular power in favor of his middle son, Stefan. Nemanja/Simeon's short time at Studenica was followed by his withdrawal to Mt Athos. He started a joint endeavor with his sons Sava and Stefan to build the second most important house of the Theotokos, the Chilandar Monastery.

Before retreating to Mount Athos, Nemanja/Simeon handed over Studenica to his middle son, Stefan the First-Crowned: 'I have given you a temple of the Most Holy Theotokos Evergetis in Studenica, to be managed and governed solely by you and only your descendants' ${ }^{93}$ Nemanja/Simeon's choice to leave Studenica to Stefan the First-Crowned symbolized his choice of his middle son to become his successor.

This crucial transfer of power was conducted under the protection of the Theotokos. The ideological, political, and hierotopical importance of Studenica as a proxy of Constantinople lies in Nemanja's abdication. This narrative episode suggests that the destiny of this monastery lay at the center of the political clash between Stefan Nemanja's two sons, the elder Vukan and the younger Stefan Nemanjić. The final phase of Studenica's completion after the brothers were reconciled suggests that Studenica was a focal point in the war between the brothers (1202-1207) ${ }^{94}$ The hypothesis that Studenica played a pivotal role in this family conflict could be read in light of a recent observation by Srđan Pirivatrić. He proposes that the construction of Studenica could have been connected to the betrothal of young Stefan (in 1186) to a member of the emperor's family. This context conforms with Studenica's ideological polysemy. ${ }^{95}$

The completion of Studenica's frescos is dated to 1208/9. This crucial historical moment is confirmed in an inscription on the ring underneath the dome (emphasis added):

This temple, dedicated to the Theotokos, was built by Stefan Nemanja, the affine of the Greek emperor kir Alexios, remembered by his monastic name Simeon, and was decorated with paintings through the endeavors of the [grand župan] and [sebastocrator] Stefan with his brother, the grand prince [veliki knez] Vukan. Do mention me, Sava the sinful, who also worked there. ${ }^{96}$

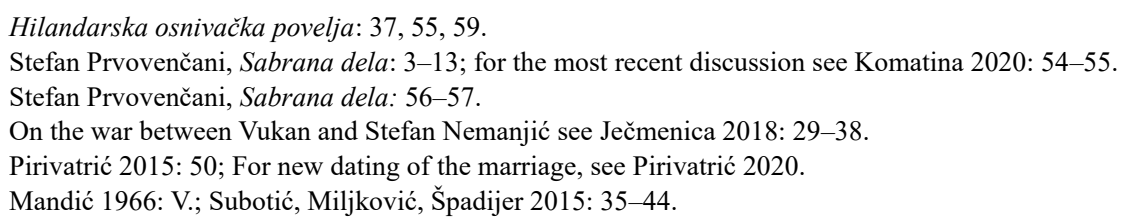


The Second Chilandar Charter and this inscription were both composed after the dissolution of Stefan's marriage to Eudokia. Nevertheless, in these two textual and visual spaces - Chilandar and Studenica - he remains sebastocrator and closely associated with the Byzantine emperor. ${ }^{97}$ It is plausible that Stefan Nemanja's affinity with the emperor, and his own precedence within the family through his son Stefan the First-Crowned, was born out in these two prominent foundations. Also, the inscription visually affirms Nemanja's final decision concerning the family hierarchy and Stefan Nemanjić's precedence. Studenica's textual, visual, and spatial rhetoric attest to the immense importance of this space for the members of the early Nemanjić dynasty. In the inscription, all three brothers are named together, but in the prescribed order of precedence. At the same time, the visual elements also record all of Nemanja's sons. In fact, the only surviving portrait of the eldest son, Vukan, is preserved at Studenica. ${ }^{98}$ It is also highly probable that Vukan spent his last days at Studenica, just as Stefan the First-Crowned did, and he was buried there 'next to the grave of his father, Simeon'. As the burial place of Stefan Nemanja and his wife Ana; two of their sons, Stefan the First-Crowned and Vukan; and Vukan's son Đorđe; Studenica was a strong emulation of the imperial mausoleum at Christ Pantokrator. ${ }^{99}$

Stefan the First-Crowned built his legitimacy under the protection of the Theotokos, and all his literary texts are imbued with the presence of Theotokos. In his charter for the Benedictine Monastery of St. Mary on the island of Mljet (c. 1220), Stefan the FirstCrowned refers to the Theotokos Evergetis as his special protectress. She is addressed as the one 'who chose him to be the heir to his father's house, and who had raised him above his brothers to feed his father's flock'. ${ }^{100}$ One can surmise that the text of the charter was either visually accessible at the monastery (like at Studenica, for example), or if not, was read aloud on special occasions. The performative dimension of reading these lines suggests the enactment of 'bringing into being the things they named', which means that Stefan's 'chosen-ness' was regularly proclaimed and invoked.

It would also make sense that the Theotokos's special protection was a political manifesto for Stefan the First-Crowned against his brother Vukan. It is also rather peculiar that, among the four monasteries with royal status at the time of Stefan the First-Crowned, three were dedicated to the Theotokos: Studenica, Chilandar, Bogorodica Gradačka, and St. George of Ras. ${ }^{101}$

Bogorodica Gradačka was a monastery built by the elder brother of Stefan Nemanja, knez Strazimir, around $1190 .{ }^{102}$ Although there is little information about this monastery, it seems it was built around the same time as Studenica. And it is highly peculiar that, soon after Strazimir's death, it was given second place in the monastic hierarchy, immediately beneath the abbot of Studenica.

Before his death, Stefan the First-Crowned was administered monastic vows by his brother Sava at Studenica, and became monk Simon. He was buried at Studenica, symbolically

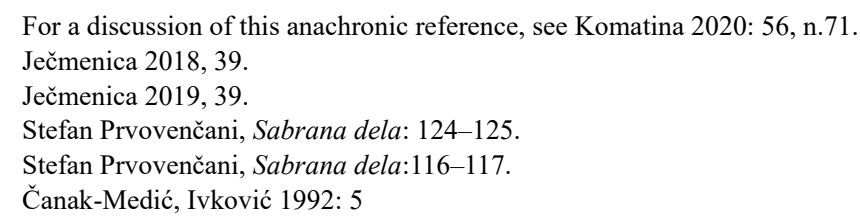


fulfilling the vow Stefan Nemanja had given to the Most Holy Theotokos. The translation of his remains to the Žiča Monastery very soon afterward perfectly follows the pattern of consecration for new holy spaces in Serbia first sanctioned by the Theotokos of Constantinople. Sava Nemanjić brought the veil and girdle of the Virgin Mary and the Icon of the Mother of God back with him after his travels in Palestine. ${ }^{103}$ These relics were deposited in the newly built Church of the Holy Savior at the Žiča Monastery, which became the center of the Serbian Autocephalous Church (1219) and where Serbian kings were coronated. ${ }^{104}$ Miljković contends that Žiča also had a much-worshipped icon of the Mother of God; ${ }^{105}$ however, the icon did not survive. It was most probably in the style of the Virgin Theotokos of the Passion, a new style of icon Sava incorporated at Chilandar and later at Žiča. ${ }^{106}$

\section{Conclusion}

There is a story in the Studenica Typikon about 'the Miracle in the monastery of the Most Holy Theotokos, the Great Intercessor, on Great and Holy Tuesday'. Although the date of its composition is uncertain, the story tells of a living cult of the Theotokos formed around the story of her apparition. It was in the style of the Mother of God enthroned, holding Jesus Christ in her arms, and 'singing somehow peacefully with her most pure voice' along with the monks 'until the very end of the prayer'. ${ }^{107}$

The name of this story, which focuses on Tuesday and the Theotokos enthroned with the baby Jesus, suggests the apparition of the Virgin Hodegetria, the palladium of the empire, in which the Tuesday rite was the day of her holy miracle. ${ }^{108}$ This story was a confirmation of the Theotokos' supernatural presence. ${ }^{109}$ Moreover, it is not surprising that a miraculous apparition was connected to Studenica.

A reference to incenses during the Ninth Ode, which was sung, alludes to the Nativity canon and the Ninth Ode, which celebrates the Mother of God. During ordinary week days or all feast days, the Ninth Ode has a katabasia, during which the cantors descend from their stalls and gather in the middle of the church to sing together. ${ }^{110}$ The story tells of angels appearing and the sweet odors surrounding them. The apparition of the Mother of God reappeared every Wednesday and Friday, on Holy Sunday, during the Lord's Feasts, and on the feasts of the holy saints. ${ }^{111}$

The story is a testimony of the envisaged experience of the Theotokos, a testimony of the spatial icon that is 'in constant movement, transforming as a living milieu formed with ritual gestures, lights, aromas and even with the most active human perception which

103 Stefan Prvovenčani, Sabrana dela: 110-111.

104 Cf. Čanak-Medić, Popović, Vojvodić, 2016: 44.

105 Miljković 2020, 129.

106 Tatić-Đurić 2000; Miljković 2020, 130.

107 Studenički tipik, 72a-72b.

108 cf. Lidov 2004, 274-276.

109 Lidov 2004, 288.

110 Perry, Melling 1999: 280.

111 Studenički tipik, 73b. 
reacts anew at the surrounding world every second'. ${ }^{112}$ We also see the potential of the liturgical performance to recreate the Divine presence. Incorporated within the Studenica Typikon, the story of the apparition testifies to the tradition of the cult in this particular space and enables us to trace the performative force of the intersection of space, liturgy, and participants and the sensation of the Theotokos hierotopy in medieval Serbia.

Apart from being 'a repository of Constantinopolitan images' ${ }^{113}$ Studenica played a key role in the sensory experience of the Divine presence, in which the focal mediators were the founders of the medieval Serbian state: Stefan Nemanja/Simeon, Sava, and Stefan Nemanjić. The visual program at Studenica, in which the Bogorodica Studenička was painted above the abbot's throne, 'adjacent to the figure of St. Saba the Sanctified, [...] the namesake and supreme role model of Sava the Serbian', very close to the ktetor's composition, formed a new image/paradigm of the Holy founders sanctified by the Theotokos Evergetis (Figures $4,5,6)$. The Bogorodica Studenicka icon was in the style of the Virgin Kyriotissa, the most highly revered style of the standing Virgin in the Komnenian period and a symbol of Orthodoxy. ${ }^{114}$ Symbolic connection between Sava and the Virgin Kyriotissa, according to Mirjana Tatić-Đurić, is based on the iconography of the Sinaite icon in which St. Sava the Sanctified prays before the Virgin Kyriotissa. In Hagia Sofia, the Virgin Kyriotissa was depicted in a mosaic of Emperor John II Komnenos in between him and his wife, Eirene Piroshka. Tatić-Đurić also observes that this icon as the mosaic icon in Hagia Sophia might have been a decisive reason for Sava introducing it as Studenica's main icon. ${ }^{115}$

Apart from being denoted as an immovable repository of sacred images, Studenica was a living space for the Theotokos through repeated rituals celebrating and exhalting her and the founders. Suppose for a moment that the veneration of the Theotokos was similar to veneration at the Monastery of Kosmosoteira (a royal monastery established by the Evergetis Typikon). One could thus imagine a community of the monks assembling before the Icon of the Mother of God and 'performing trisagion every evening' for the mercy of its founder soul. ${ }^{116}$ On the feasts dedicated to the Theotokos throughout the year the solemnity of the occasion in the Kosmosoteira typikon stipulated the following:

There should be four lamps lit in the very middle of the church, and two candelabra with eight candleholders should stand by the two icons set out for veneration, that is, in the two parts of the Church where my Supremely-good Christ, and the Mother of God and Kosmosoteira, are respectively represented with great skill, so that the images appear alive to the beholder, and as though letting out a beautiful sound from their mouths toward him. ${ }^{117}$

In the same vein, the images of the holy founders of Studenica, 'alive and yet unmoving in space, ${ }^{118}$ united around the image of the Bogorodica Studenička, stand as a living testament of their sacral and royal status.

The many faces of the Theotokos in Studenica-the Virgin Hodegetria,

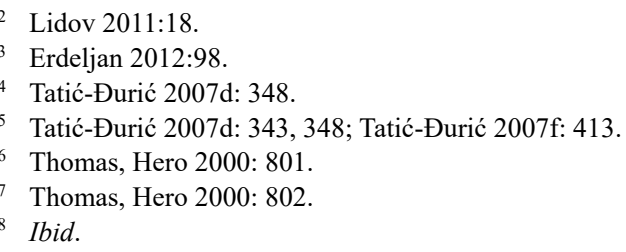


Blachernitissa, and Kyriotissa - accorded the founders sanctity and featured as symbolical images for the reconfiguration of the Serbian polity as a new dwelling place for the Thetokos (Figure 7). The Virgin Blachernitissa, found on the seals in the circle of the imperial family, was also specific to the Komnenian period. As Ousterhout points out, the image's popularity might have been directly connected to the imperial residence being moved to the Palace of Blachernae. ${ }^{119}$ In addition to its intimate connection to the imperial residence, an icon of the Virgin Blachernitissa was carried into battle by eleventh-century emperors. ${ }^{120}$ Although Ousterhout's conclusion about the ideological importance of the Blachernitissa within the Chora's decorative program (1315-1321) deals with events occurring more than a century after Studenica was built, his conclusion might be useful for understanding that of Studenica. He concludes that with 'the language of the Chora's decorative program, Metochites joined the ranks of the imperial family and placed himself under the same spiritual protection'. ${ }^{121}$ In the same vein, the monastery of Studenica, along with the performative aspects of its sacred space dedicated to the Theotokos, asserted the early Nemanjić's place among the members of the imperial family.

Put under the protection of the supreme holy protector of Constantinople, Studenica was undoubtedly a manifesto for the new political direction undertaken by Stefan Nemanja, Sava, and Stefan the First-Crowned. The construction of the Theotokos's sacred space in Serbia enabled the enactment of a ritual that gave divine sanction to the formation of both an independent Serbian Church and an independent Serbian state.

\section{REFERENCES:}

Sources:

'Hilandarska osnivačka povelja Svetoga Simeona i Svetoga Save', pr. Đorđe Trifunović, Vesna Bjelogrlić, Irena Brajović, u: Osam vekova Studenice: zbornik radova, Beograd: Sveti arhijerejski sinod 1986, 49-61. (Serbian Cyrillic)

Domentijan, Život Svetoga Simeuna i Svetoga Save, pr. Đ. Daničić, Beograd: Državna štamparija 1865 (Srbian Cyrillic)

Stefan Prvovenčani. Sabrana Dela, Lj. Juhas-Gerogievska, T. Jovanović (pr.), Beograd: Srpska književna zadruga 1999. (Serbian Cyrillic)

Studenički Tipik. Carostavnik manastira Studenice, T. Jovanović (pr.), Beograd: Zavod za udžbenike i nastavna sredstva: Narodna Biblioteka Srbije 1994. (Serbian Cyrillic)

Sveti Sava, The Studenica Typikon, ed. M. Anđelković, archimandrite T. Rakićević, Monastery of Studenica 2018.

Secondary literature:

Babić, G. Korać, V. Ćirković, S. Studenica. Beograd: Jugoslovenska revija, 1986. (Serbian Cyrillic)

Bacci, M. 'Sacred Spaces versus Holy Sites: on the limits and advantages of a hierotopic approach', in: J. Bogdanović (ed.), Icons of Space. Advances in Hierotopy, London and New York: Routledge, 2021, 15-29.

\footnotetext{
${ }^{119}$ Ousterhout 1995: 94

${ }^{120}$ Ousterhout 1995: 96.

${ }^{121}$ Ousterhout 1995: 96.
} 
Bal, M. Narratology: Introduction to the Theory of Narrative (trans. C. van Boheemen), Toronto: University of Toronto Press, 1985.

Bubalo, Đ. 'Još jednom o godini smrti kralja Stefana Prvovenčanog', u: I. Komatina (pr.), Stefan Prvovenčani i njegovo doba, Beograd: Istorijski institut, 2020, 99-119.

Butler, J. Bodies that Matter, London and New York: Routledge, 1993.

Čanak-Medić, M. Zorica, I. Bogorodica Gradačka, Beograd: Republički zavod za zaštitu spomenika kulture, 1992. (Serbian Cyrillic)

Čanak-Medić, M. Popović, D. Vojvodić, D. Manastir Žiča, Beograd: Republički zavod za zaštitu spomenika kulture, 2016. (Serbian Cyrillic)

Congdon, E. A. 'Imperial Commemoration and Ritual in the Typikon of the Monastery of Christ Pantokrator,' Revue des études byzantines, 54, 1996, 161-199.

Culler, J. D, 'Philosophy and Literature: The Fortunes of the Performative', Poetics Today 21/3, 2000, 503-519.

Đorđević, J. Predstave umirućeg, mrtvog $i$ vaskrslog tela u vizantijskoj umetnosti od dvanaestog do petnaestog veka, Doktorska disertacija, Beograd: Univerzitet u Beogradu, Filozofski fakultet, 2019.

Đurić, V. 'Mozaička ikona Bogorodice Odigitrije iz manastira Hilandara', Zograf, 1, 1996, 16-20.

Kašić, D. Lj. 'Studenica kroz vekove', in: Episkop Žički Stefan et al. (pr.) Osam vekova Studenice: zbornik radova, Beograd: Srpski arhijerejski sinod, 1986, 13-32. (Serbian Cyrillic)

Erdeljan, J. 'A Contribution to the Study of Marian Piety and Related Aspects of Visual Culture in Late Medieval Balkans: Several Notable Examples recorded in Serbian Written Sources', IKON, 10, 2017, 369-376.

. 'Studenica. A New Perspective?', in: M. Angar and C. Sode (eds.), Serbia and Byzantium: Proceedings of the International Conference Held on 15 December 2008 at the University of Cologne, Frankfurt am Main: PL Academic Research, 2013, 33-43.

. 'Studenica. An identity in marble', Zograf, 35, 2011, 93-100. (Serbian Cyrillic)

. 'Studenica. All Things Constantinopolitan', in: I. Stevović (ed.), IYMMEIKTA, Collection of Papers in Honor of $40^{\text {th }}$ Anniversary of the Institute of Art History, Faculty of Philosophy, University of Belgrade, Belgrade: Institut za Istoriju umetnosti, 2012, 93-102.

Hristu, P. K. 'Manastir presvete Bogorodice Evergetidske u Carigradu', u: Episkop Žički Stefan et al. (pr.), Osam vekova Studenice: zbornik radova (pr.), Beograd: Srpski arhijerejski sinod, 1986, 61-73.

Ječmenica, D. Nemanjići Drugog Reda, Beograd: Filozofski fakultet, 2018.

Kašanin, M. Čanak Medić, M. Maksimović, J. Todić, B. Šakota, M. Manastir Studenica, Beograd: Književne novine, 1986.

Komatina, I. 'I obnovi svoju dedovinu i bolje je utvrdi - Stefan Nemanja i Stefan Prvovenčani i uobličavanje srpske državnosti', u: I. Komatina (pr.) Stefan Prvovenčani i njegovo doba, Beograd: Istorijski institut, 2020, 37-63.

Korać, V. 'Arhitektura i Skulptura', U: Studenica, Beograd: Književne Novine, 1986, $29-70$.

Lidov, A. 'The Flying Hodegetria.The Miraculous Icon as Bearer of Sacred Space', In: E. Thunoe and G. Wolf (eds.), The Miraculous Image in the Late Middle Ages and Renaissance, Rome, 2004, 273-304.

. 'Spatial Icons. The Miraculous Performance with the Hodegetria of Constantinople', in: A. Lidov (ed.), Hierotopy. Creation of Sacred Spaces in Byzantium and Old Russia, Moscow: 'Progress-tradition', 2006b, 349-372.

. 'Hierotopy. The creation of sacred space as a form of creativity and subject of cultural history', in: A Lidov (ed.), Hierotopy. Creation of Sacred Spaces in Byzantium and Old Russia, Moscow: 'Progress-tradition', 2006a, 33-58. 
. 'The Byzantine World and Performative Spaces', in: A. Lidov (ed.), Spatial icons. Performativity in Byzantium and Medieval Russia (foreword), Moscow: Indrik, 2011, 17-26.

Magdalino, P. 'The Foundation of the Pantokrator Monastery in Its Urban Setting', in: S. Kotzabassi (ed.), The Pantokrator Monastery in Constantinople, Boston/Berlin: De Gruyter 2013, 33-57.

Mandić, S. Bogorodičina crkva u Studenici, Beograd: Izdavački zavod Jugoslavija, 1966. (Serbian Cyrillic)

Marinis, V. 'He Who Is at the Point of Death': The Fate of the Soul in Byzantine Art and Liturgy. Gesta, 54(1), 2015, 59-84.

Marjanović-Dušanić, S. 'Vladarski znaci Stefana Nemanje', u: J. Kalić (pr.), Stefan Nemanja, Sveti Simeon Mirotočivi. Istorija i Predanje, Beograd: SANU, 2000, 77-87.

. Vladarska ideologija Nemanjića. Diplomatička studija. Beograd: Srpska književna zadruga, 1997.

Marković, M. 'Srbija u Vizantiji - Ktitorska delatnost srpskih zadužbinara na području Romejskog carstva', u: D. Popović, D. Vojvodić (pr.), Sakralna umetnost srpskih zemalja u Srednjem veku, Beograd: Službeni glasnik, 2016, 57-73.

. 'Srbija u Vizantiji - Ktitorska delatnost srpskih zadužbinara na području Romejskog carstva'. U: D. Popović, D. Vojvodić (pr.), Sakralna umetnost srpskih zemalja u srednjem veku. Vizantijsko nasleđe i srpska umetnost, 2 tom. Beograd: Službeni glasnik, 2016, 57-73.

Miljković, B. Žitija Svetog Save kao izvori za istoriju srednjovekovne umetnosti, Beograd: Vizantološki institut SANU, 2008.

. 'Naročito poštovane ikone u srednjovekovnoj Srbiji', Zograf, 44, 2020, 127-156. (Serbian Cyrillic)

Ousterhout, R. 'Interpreting the Construction History of the Zeyrek Camii in Istanbul (Monastery of Christ Pantokrator)', in Studies in Ancient Structures: Proceedings of the Second International Conference, Istanbul, 2001, I: 19-27.

. 'Sacred Geographies and Holy Cities: Constantinople as Jerusalem', in: A. Lidov (ed.), Hierotopy: The Creation of Sacred Space in Byzantium and Medieval Russia, Moscow: Indrik, 2006, 98-116.

. 'The Virgin of the Chora: An Image and Its Contexts', in: R. Ousterhout, L. Brubaker (eds.), The Sacred Image East and West, Chicago: University of Illinois Press, 1995, 91-110.

. 'Byzantine Funerary Architecture of the Twelfth Century', in: A. Leonidovich Batalov and O. Evgen'evna Ètingof (eds.), Drevnerusskoe iskusstvo. Rus' i strany vizantijskogo mira. XII vek, Sanct Peterburg: Dmitrij Bulanin, 2002.

. 'Architecture, Art and Komnenian Ideology at the Pantokrator Monastery', in: N. Necipoğlu (ed.), Byzantine Constantinople: Monuments, Topography, and Everyday Life, Leiden: Brill, 2001, 133-150.

. 'Architecture and patronage in the age of John II', in: A. Bucossi and A. Rodriguez-Suarez (eds.), John II Komnenos: In the shadow of Father and Son, New York: Routledge, 2016, 135-155.

Ousterhout, R. R. Ahunbay, Z. Ahunbay, M. 'Study and Restoration of the Zeyrek Camii in Istanbul', Second Report 2001-2005, Dumbarton Oaks Papers, 63, 2010, 235-256.

Pentcheva, B. Icons and Power. The Mother of God in Byzantium. The Pennsylvania State University Press: University Park, PA, 2006.

Petrey, S. Speech Acts and Literary Theory, New York: Routledge, 1990.

Petrović, M. 'Crkveno-državna ideologija svetoga Save u Studeničkom tipiku', u: Episkop Žički Stefan et al. (pr.), Osam vekova Studenice: zbornik radova, Beograd: Srpski arhijerejski sinod, 1986a, 75-83. (Serbian Cyrillic)

. Studenički tipik i samostalnost srpske crkve, Gornji Milanovac: Dečje Novine, 1986b. 
Pirivatrić, S. 'Brak Stefana Nemanjića i Evdokije Anđeline Komnine. Hronologija i istorijski kontekst ugovaranja i raskida jednog dinastičkog saveza'. u: I. Komatina (pr.), Stefan Prvovenčani i njegovo doba, Beograd: Istorijski institut, 2020, 139-159.

. 'Hronologija i istorijski kontekst podizanja manastira Studenice. Prilog istraživanju problema', Zograf, 39, 2015, 47-56.

Popović, D. Srpski vladarski grob u srednjem veku, Beograd: Institut za istoriju umetnosti Filozofskog fakulteta, 1992.

Popović. M. (pr.). Manastir Studenica - arheološka otkrića. Beograd: Republički zavod za zaštitu spomenika, 2015. (Serbian Cyrillic)

Radojičić, Đ. 'Zašto je Studenica posvećena Sv. Bogorodici Blagodeteljnici Evergetidi', Bogoslovlje, XI/3-4, Beograd, 1936, 294-300.

Sauerbaum, A. and Gragnolati, M. 'Medieval culture 'betwixt and between': An introduction', in: A. Sauerbaum and M. Gragnolati (eds.), Aspects of the Performative in Medieval Culture, Boston/Berlin: De Gruyter, 2010, 1-12.

Stanković, V. 'Comnenian Monastic Foundations in Constantinople: Questions of Method and Context', Beogradski istorijski glasnik, 2, 2011, 47-72.

. Komnini u Carigradu (1057-1185). Evolucija jedne vladarske porodice. Beograd: Vizantološki institut SANU, 2006.

Stare srpske biografije, D. Bogdanović (pr.), Beograd: Prosveta, 1968. (Serbian Cyrillic)

Stevović, I. 'Istorijski Izvor i istorijskoumetničko tumačenje: Bogorodičina Crkva u Toplici', Zograf, 35, 2011, 73-92.

Subotić, G. Miljković, B. Špadijer, I. Natpisi istorijske sadržine u zidnom slikarstvu, Tom prvi, XIIXIII vek, Beograd: Viyantolo[ki institut SANU, 2015.

Taft, R. Liturgy in Byzantium and Beyond, Farnham: Ashgate Publishing, 1995, 45-75.

Tatić-Đurić, M. 'Bogorodica Strasna u Žiči', u: G. Subotić (pr.), Manastir Žiča. Zbornik radova, Kraljevo: Narodni muzej, 2000, 149-163. (Serbian Cyrillic)

. 'Iz naše srednjovekovne mariologije - Ikona Bogorodice Evergetide', u: Studije o Bogorodici, Beograd: Jasen 2007a: 51-70.

. 'Ikone Bogorodice Beogradske', u: Studije o Bogodorici, Beograd: Jasen, 2007b, 199-212.

. 'Ikonografija Bogorodice Strasne, nastanak dogme i simbola', u: Studije o Bogodorici, Beograd: Jasen 2007c, 275-299.

. 'Studenička Bogorodica Kiriotisa', u: Studije o Bogodorici, Beograd: Jasen, 2007d, 343-351.

. 'Književna inspiracija u ikonografiji Bogorodice', u: Studije o Bogodorici, Beograd: Jasen, 2007e, 351-369.

. 'Ikone Bogorodice u Studenici', u: Studije o Bogodorici, Beograd: Jasen, 2007f, 405-419.

. 'Bogorodica u delu arhiepsikopa Danila', u: Studije o Bogodorici, Beograd: Jasen, 2007g, $463-487$.

. 'Bogorodica Strasna u Žiči', u: Studije o Bogodorici, Beograd: Jasen 2007h, 607-623.

. Studije o Bogodorici, Beograd: Jasen 2007.

The Blackwell Dictionary of Eastern Christianity. K. Parryand, D. Melling (eds.), Malden, MA: Blackwell Publishing, 1999.

Thomas, J. Hero, A. C. (eds.). Byzantine monastic foundation documents. A Complete Translation of the Surviving Founders' Typika and Testaments, Washington: Dumbarton Oaks Research Library, 2000.

Veikou, M. 'Space in Texts and Space as Text: A new approach to Byzantine spatial notions', Scandinavian Journal of Byzantine and Modern Greek Studies, 2, 2016, 143-177.

Živojinović, M. 'Hilandarski i Evergetidski tipik. Podudarnosti i razlike', Zbornik Radova Vizantološkog instituta, 33, 1994, 85-101.

. Istorija Hilandara. Od osnivanja 1198. do 1335, Beograd: Prosveta, 1998. (Serbian Cyrillic) 


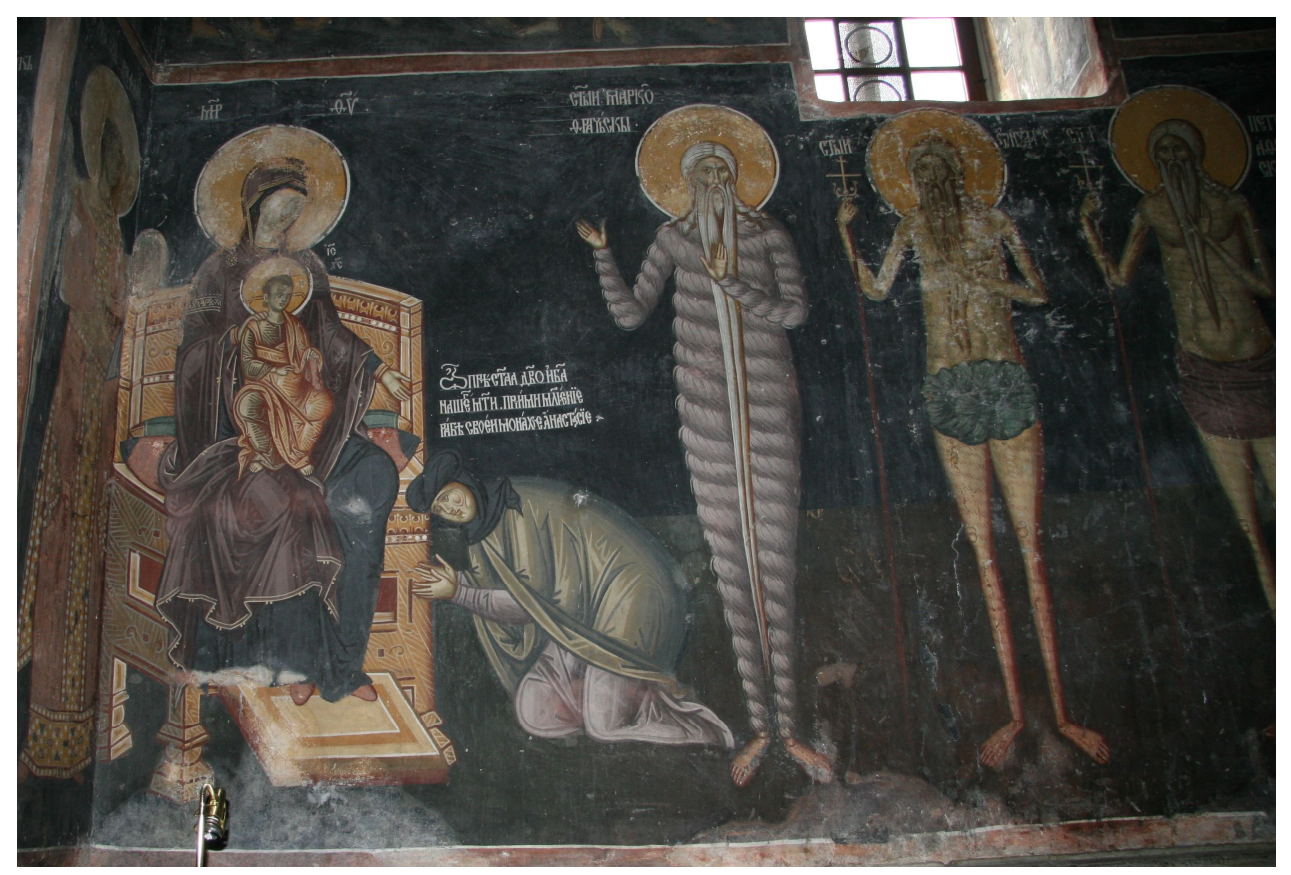

Fig. 1. Theotokos Hodegetria and Ana/Anastasija (Source: Jakov Đorđević, private archive) 


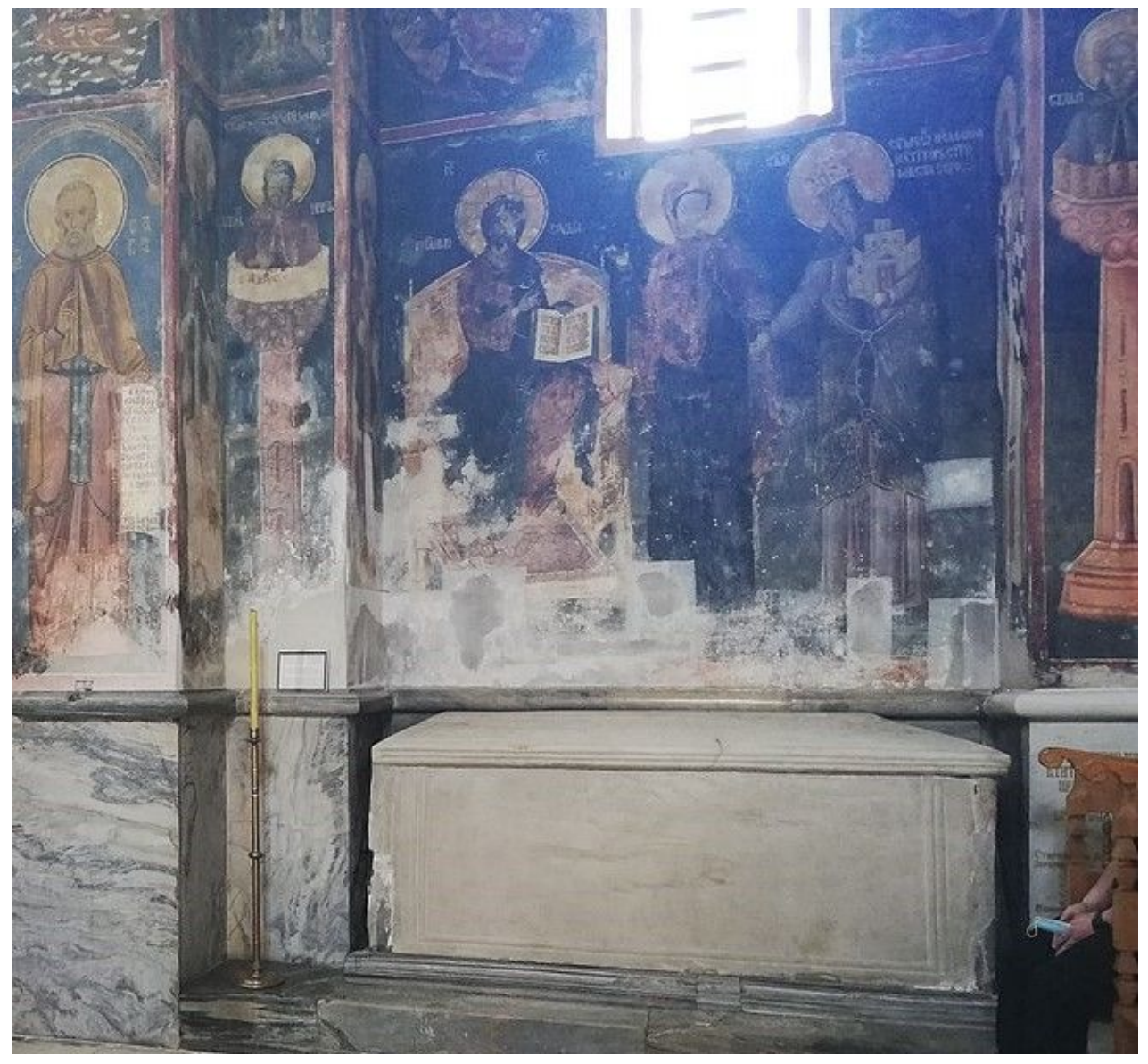

Fig. 2. Tomb of Stefan Nemanja, Studenica. The composition above the tomb:

Stefan Nemanja offers his endowment to Christ through the mediation of the Theotokos.

(Source: https://commons.wikimedia.org/wiki/File:Grob_Stefana_Nemanje,_manastir_Studenica.jpg) 


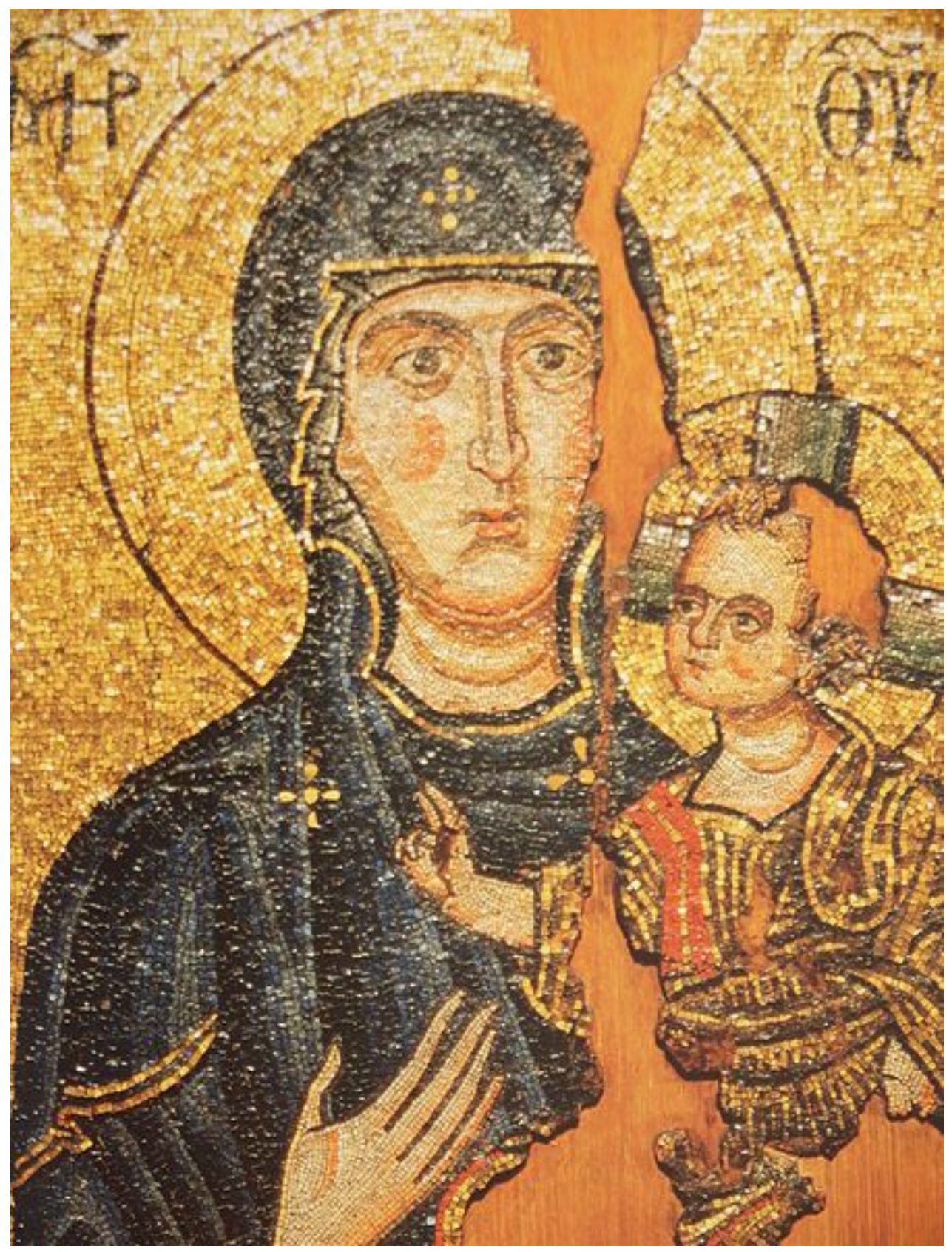

Fig. 3. Mosaic icon of Theotokos Hodegetria, XII century, Chilandar Monastery, Mount Athos (Source: https://www.wikiart.org/en/orthodox-icons/hodegetria-1300-0) 


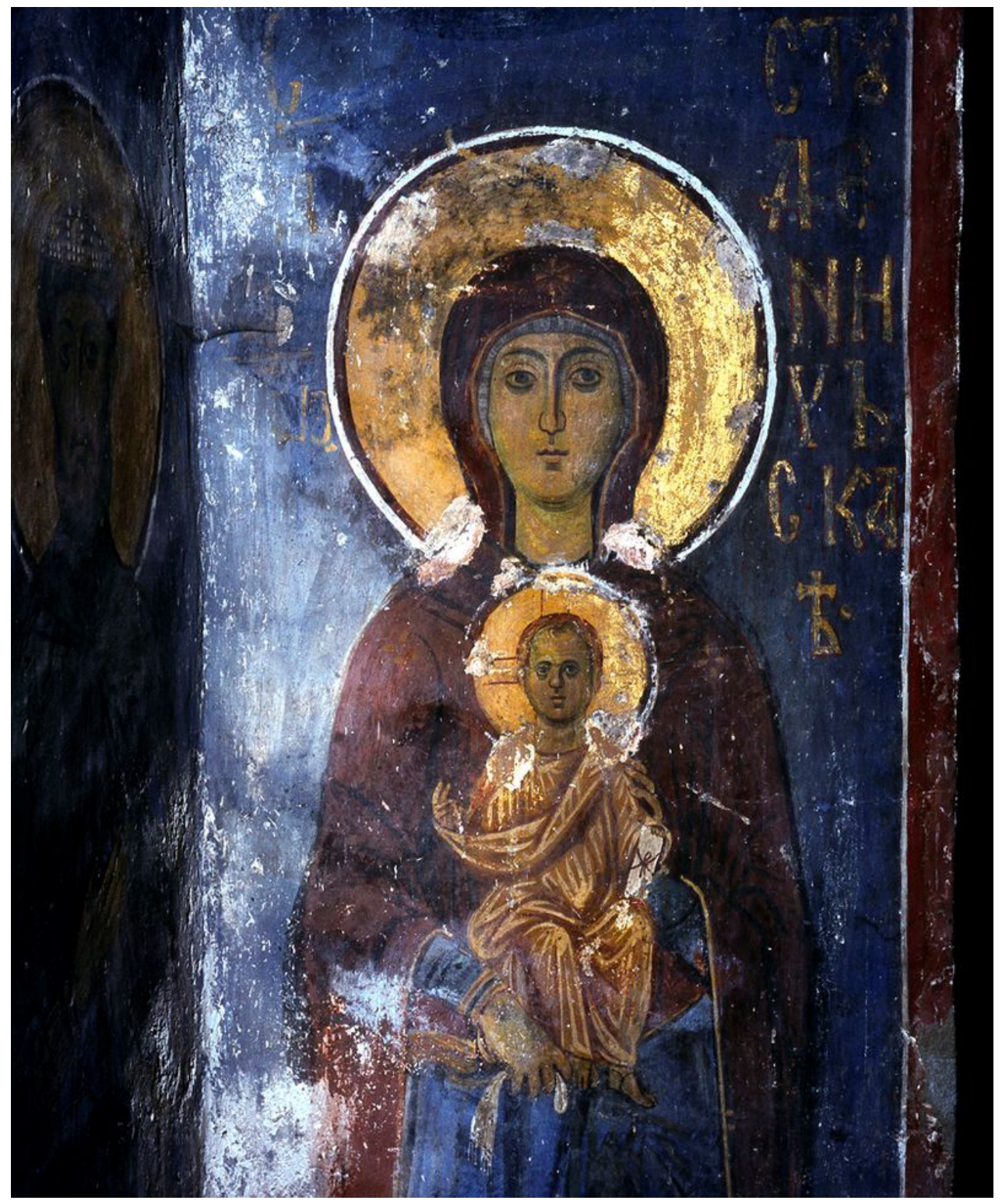

Fig. 4. Theotokos of Studenica (Bogorodica Studenička)

Source: https://commons.wikimedia.org/wiki/File:Ikona_Bogorodice_Studeni\%C4\%8Dke.jpg 


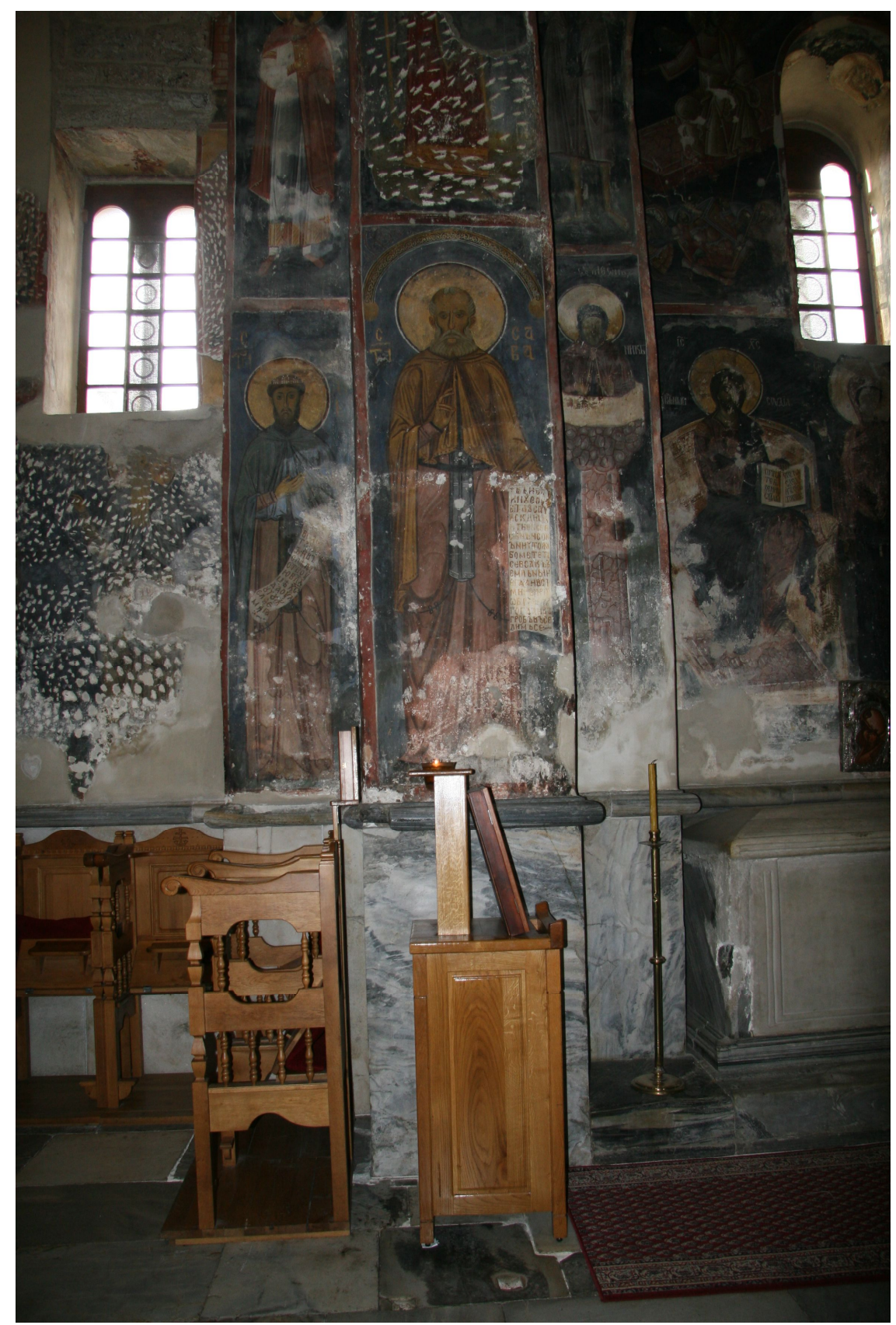

Fig. 5. View at the abbot's throne from the side with representations of St Josaphat (to the left) and St Sabbas the Sanctified (to the left).Monastery of Studenica (Source: Jakov Đorđević, private archive) 


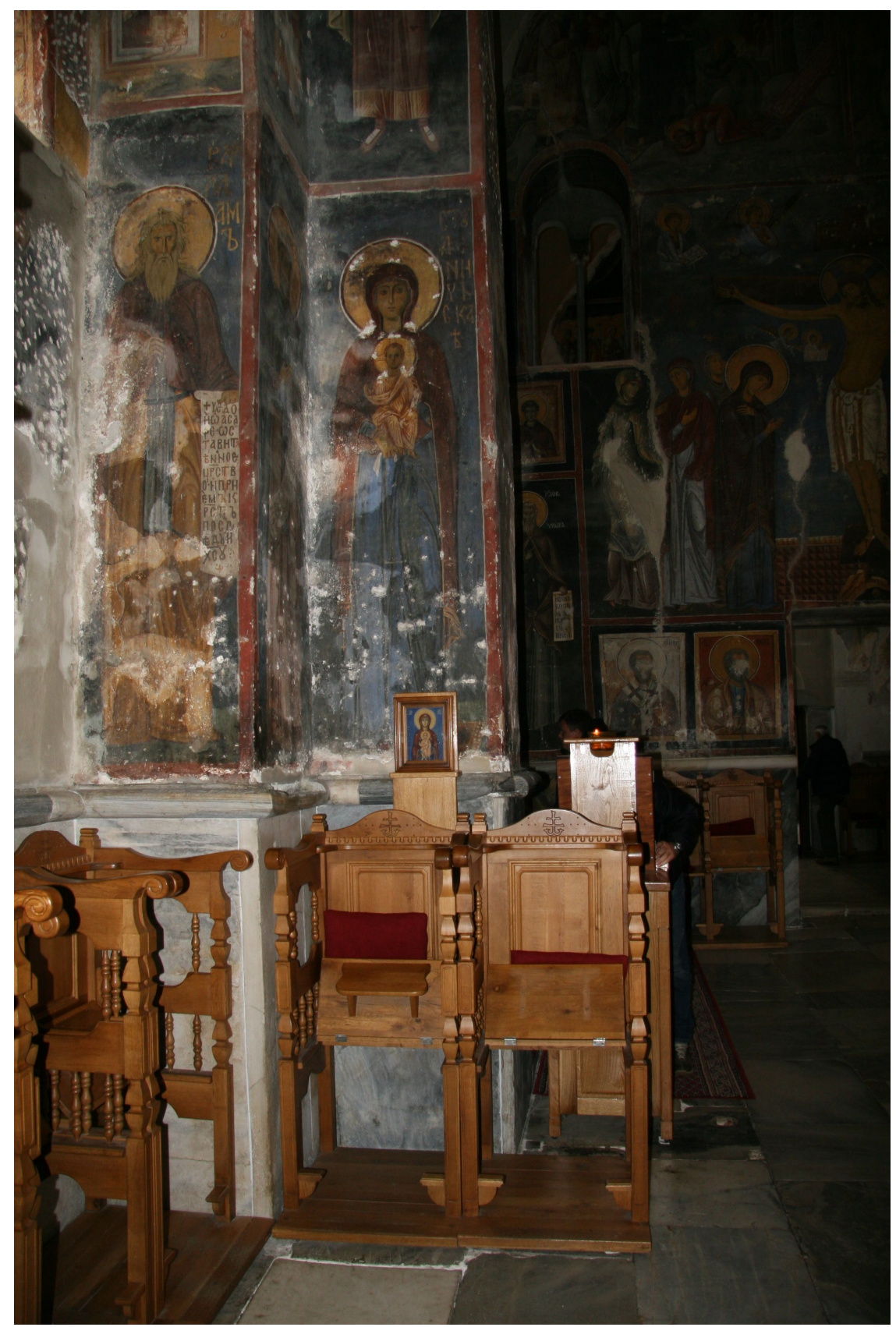

Fig. 6. The fresco of 'the Mother of God of Studenica' (Bogorodica Studenička) above the abbot's throne. Monastery of Studenica (Source: Jakov Đorđević, private archive) 


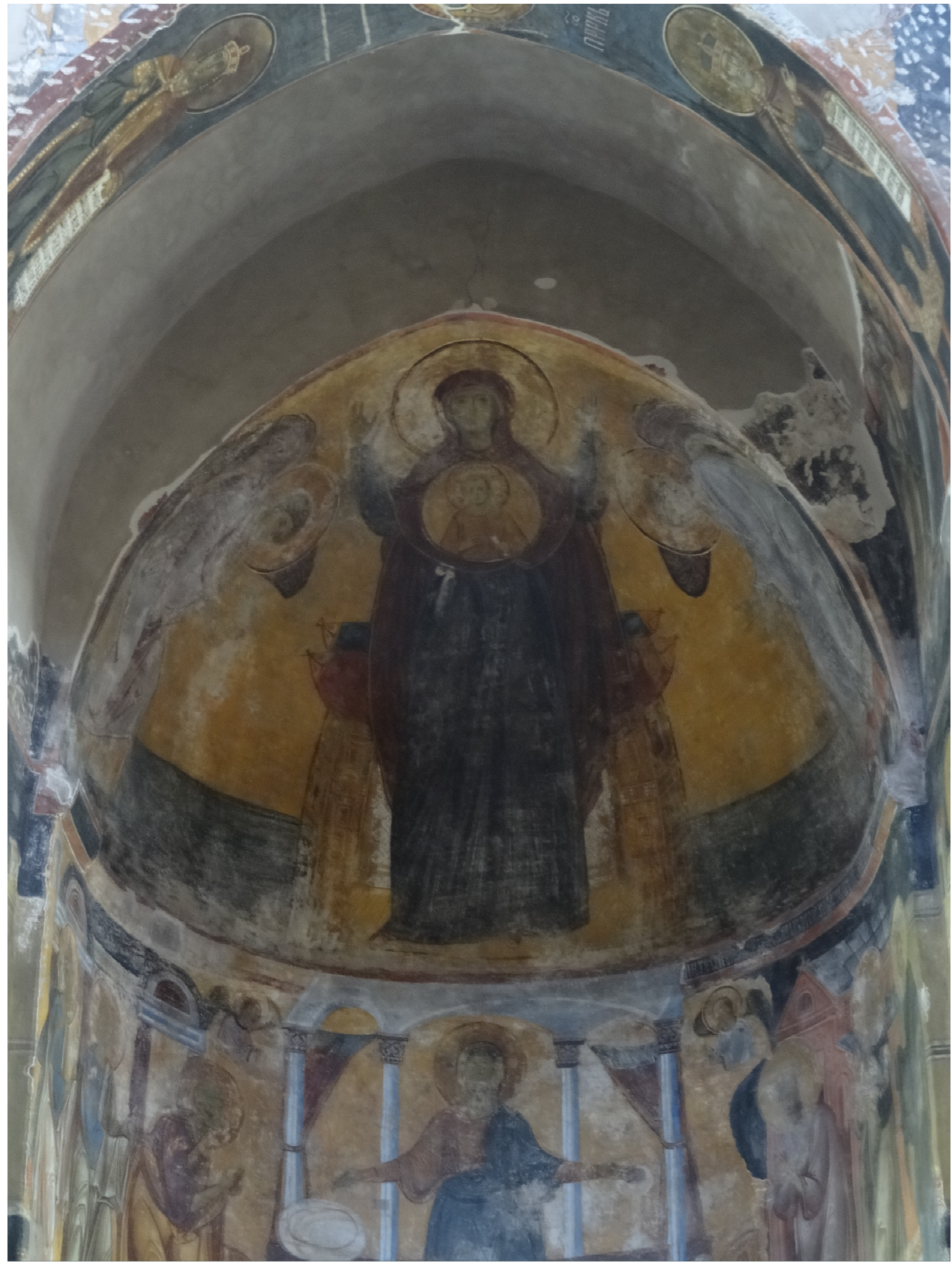

Fig. 7. Theotokos Balchernitissa in the apse, Monastery of Studenica (Source: https://commons.wikimedia.org/wiki/Category:Studenica_Monastery\#/media/ File:Manastir_Studenica,_Srbija,_020.JPG) 


\section{ЛАРИСА ОРЛОВ ВИЛИМОНОВИТ}

Универзитет у Београду, Филозофски факултет

\section{КУЛТ БОГОРОДИЦЕ И ОСНИВАҢЕ ДРЖАВЕ НЕМАЫИЋА: ЧИТАЫЕ ИЗМЕЪУ СЛИКЕ И ПЕРФОРМАНСА}

\section{Резиме}

Идеја рада је да кроз теорију перформанса, односно кроз перформативност слике, текста и простора понуди ново читање идеолошких премиса на којима се заснивало оснивање државе Немањића.

Прво поглавље је посвећено уводу у концепт перформативности и проблематизацији изворног материјала, односно методолошком приступу изворима. Такође, уводи се култ Богородице као студија случаја кроз који ће се кроз рад пратити политичка идеологија ране државе Немањића.

Друго поглавље „Стефан Немања и Богородица' започиње анализу штовања Богородичиног култа у доба раних Немањића, са фокусом на две најзначајније задужбине подигнуте у време Стефана Немање и посвећене Богородици, уз тумачење сцене Немањине смрти и његовог завета Богородици у контексту значаја култа Одигитрије у време Комнина и њеног потенцијала за стварње живуће слике Богородице која својим присуством благосиља и санкционише нови светитељски култ Светог Симеона.

Треће поглавље „Приступ полисемији Студенице' је усмерено на централну тему рада, истичући превасходно вишезначност Студенице у визуелном и просторном смислу као обитавалишту Богородице у Србији.

Четврто поглавље „Свети Сава и Студеница' се усмерава на литургијску хијеротопију, анализирајући идеолошку и политичку позадину посвете Богородици Благодетељници и проблематизујући аспекат ритуала који је у фокус стављао Богородицу.

Пето поглавље „Стефан Првовенчани и Богородица' се усмерава на идеолошки програм Стефана Првовенчаног који је на више равни почивао на посебној вези са Богородицом.

У закључку рад још једном повезује идеју перформанса са њеним значајем у рекреирању живуће слике Богородице и идеолошком и политичком значају те нове просторне иконе у процесу успостављања независности Српске средњовековне државе.

Кључне ријечи: Богородица, Стефан Немања, Сава, Стефан Првовенчани, перформативност, византијски обред, Богородица Евергетида, Студеница, просторне иконе. 